\title{
The effects of whole wheat, wheat bran and zinc in the diet on the absorption and accumulation of cadmium in rats
}

\author{
BY ANNCATHERINE MOBERG WING \\ The Biophysics Laboratory and the Departments of Nutritional Research and Pathology, \\ University of Umeå, S-901 87 Umeå, Sweden
}

(Received 5 August 1991-Accepted 7 January 1992)

\begin{abstract}
The purpose of the present study was to determine if the inclusion of whole-grain wheat or wheat bran in the diet or the addition of $\mathrm{Zn}$ to the diet affects the absorption and accumulation of $\mathrm{Cd}$. Five groups of six rats each were fed deionized water and one of five diets composed of one part basic diet and one part wheat crispbread for 6 weeks. The accumulation of $\mathrm{Cd}$ in the liver and kidneys was measured using atomic absorption spectrometry and estimated by measuring the absorption and retention of ${ }^{109} \mathrm{Cd}$ from a single meal after 3 weeks on the diets. The fractional accumulation of $\mathrm{Cd}$ in the liver and kidneys was lower in rats fed on whole-wheat and bran diets than in those fed on wheat-endosperm diets. As adding $\mathrm{Zn}$ or $\mathrm{Cd}$ to endosperm diets to approximate the bran and whole-wheat diet levels had no effect on the fractional Cd absorption, the reduced absorption from the whole-wheat and bran diets is probably not due to their higher $\mathrm{Zn}$ and $\mathrm{Cd}$ concentrations but may be due to their higher fibre or phytate concentrations. The amount of $\mathrm{Cd}$ accumulated in the liver and kidneys of the rats fed on whole-wheat and bran diets was higher than that in rats fed on the endosperm diet. Thus, the reduction in the fractional Cd accumulation from the whole-wheat and bran diets is not sufficient to compensate for their higher $\mathrm{Cd}$ concentrations.
\end{abstract}

Whole-grain wheat: Wheat bran: Zinc: Cadmium

$\mathrm{Cd}$ is a potentially toxic trace element. Its concentration has been increasing in the air, water, soil and crops since the beginning of the last century (Kjellström, 1986). This pollution has led to an increased exposure of humans to Cd (Elinder, 1985a,b). Food is the major source of $\mathrm{Cd}$ exposure in non-smoking individuals who are not occupationally exposed to $\mathrm{Cd}$ and not living in areas with air pollution. In the USA in 1982 the average intake of $\mathrm{Cd}$ via the diet was calculated to be $28 \mu \mathrm{g} / \mathrm{d}$. Grain and cereal products were calculated to be responsible for about one-third of the Cd intake via the food (Gartrell et al. 1986). In Sweden the average total Cd intake via the food has been calculated to be $8.5 \mu \mathrm{g} / \mathrm{d}$ (Vahter et al. 1991), $45 \%$ of which is estimated to derive from grain and cereal products (Nilsson \& Wallgren, 1987).

Wheat generally has the highest $\mathrm{Cd}$ concentration among the grains most commonly consumed and, of the different fractions of wheat grain, wheat germ and bran have the highest concentrations of Cd (Jorhem et al. 1984). In order to prevent or minimize costly health problems in both developing and developed countries, the World Health Organization (1990) recommends that the intake of complex carbohydrates and dietary fibre is increased. Increasing the intake of dietary fibre, especially that from wheat, should increase considerably the exposure to $\mathrm{Cd}$ via the diet and may also increase the body burden of $\mathrm{Cd}$ as a result. However, the fractions of wheat which are rich in dietary fibre also contain relatively high concentrations of phytic acid (de Boland et al. 1975) and minerals such as $\mathrm{Zn}$ and $\mathrm{Fe}$ (Jorhem et al. 1984) which may negatively affect the absorption 
of Cd (Flanagan et al. 1978; Jackl et al. 1985; Nordberg et al. 1985). There is little information available on the absorption and retention of naturally occurring $\mathrm{Cd}$ in the diet or the possible reduction in absorption due to the presence of naturally occurring dietary fibre, phytic acid or $\mathrm{Zn}$.

In an earlier investigation (Moberg et al. 1987) we studied the effect of wheat bran in the diet on the accumulation of $\mathrm{Cd}$ in the liver and kidneys of growing rats. The amount of $\mathrm{Cd}$ accumulated in these organs over a period of 6 weeks was determined using atomic absorption spectrometry (AAS). We also tested whether or not the accumulation of Cd could be estimated by measuring the absorption of ${ }^{109} \mathrm{Cd}$ given in a single meal of the diet. The accumulation of $\mathrm{Cd}$ in the liver and kidneys measured using AAS and that estimated from the absorption and retention of ${ }^{109} \mathrm{Cd}$ were not in agreement. While the absorption of ${ }^{109} \mathrm{Cd}$ from the test meals indicated that some factor or factors in the wheat-bran diet reduced the availability of $\mathrm{Cd}$, this was not confirmed by the $\mathrm{Cd}$ contents in the liver and kidneys after 6 weeks on the diets. These discrepancies led us to re-examine the systematic and random errors in both methods. The purpose of the present study was to repeat and extend this earlier study after modification of both methods in order to increase their accuracy and reproducibility.

The present study was, thus, designed to determine: (1) if the inclusion in the diet of wheat bran or whole-grain wheat reduces the fractional absorption and accumulation of $\mathrm{Cd}$ in rats, (2) if an increase in the diet $\mathrm{Zn}$ concentration affects the absorption and accumulation of $\mathrm{Cd}$, and (3) if the accumulation of $\mathrm{Cd}$ in the liver and kidneys measured using AAS and that estimated by measuring the absorption and retention of ${ }^{109} \mathrm{Cd}$ from a single meal of the diet are in agreement. Two experiments were performed. In the first of these the fraction of ${ }^{109} \mathrm{Cd}$ absorbed and retained in the liver and kidneys was measured at $3,6,12,24$ and $48 \mathrm{~h}$ after ingestion of a ${ }^{109} \mathrm{Cd}$-labelled test meal of the endosperm diet in order to determine how much time is necessary to obtain an accurate measurement of $\mathrm{Cd}$ absorption. In the second experiment groups of rats were given diets containing different wheat fractions and different $\mathrm{Zn}$ and $\mathrm{Cd}$ concentrations. The fractional absorption and retention of ${ }^{109} \mathrm{Cd}$ and the accumulated amounts of $\mathrm{Cd}$ in the liver and kidneys were measured to demonstrate possible differences in the $\mathrm{Cd}$ accumulated from the different diets and possible differences between the measures of $\mathrm{Cd}$ accumulation.

\section{MATERIALS AND METHODS}

Animals

In Expt 1, thirty 5-week-old male rats and in Expt 2, thirty 3-week-old male rats of the Sprague-Dawley strain (Anticimex, Sollentuna, Sweden) were used. The thirty rats in each of the two experiments were assigned by formal randomization to one of five groups of six rats each. In Expt 1 the animals were housed separately in metabolism cages of stainless steel and acrylic resin (Ehret 13-1700, Emmendingen, Germany) during the entire experiment. During the first 3 weeks of Expt 2, sub-groups of three rats from the same experimental group were housed together in standard laboratory cages of acrylic resin with stainless-steel covers. During the last 3 weeks of this 6-week experiment the rats were housed separately in metabolism cages.

\section{Experimental diets}

The diets were composed of equal parts dry weight of a basic diet and one of five different crispbreads (Table 1). The basic diet was composed of $(\mathrm{g} / \mathrm{kg})$ : potato starch 640 , milk protein 200 , maize oil 100, mineral salts 50 and vitamins 10 . The dough used in making the 
Table 1. Composition of diets $(\mathrm{g} / \mathrm{kg}$ dry weight) comprised of one part basic diet and one part crispbread*

\begin{tabular}{|c|c|c|c|c|c|}
\hline Diet... & Endosperm $\dagger$ & Whole wheat + & Bran£ & $\begin{array}{c}\text { Endosperm + } \\
\text { cadmium } †\end{array}$ & $\begin{array}{c}\text { Endosperm }+ \\
\text { zinc }{ }^{\dagger}\end{array}$ \\
\hline Ash & 39 & 42 & 47 & 39 & 37 \\
\hline Protein & 120 & 125 & 131 & 122 & 120 \\
\hline Fat & 107 & 111 & 116 & 107 & 105 \\
\hline Carbohydrate & 711 & 663 & 624 & 710 & 719 \\
\hline Dietary fibre & 23 & 59 & 82 & 22 & 19 \\
\hline Phytic acid (mmol/kg) & $0 \cdot 3$ & $4 \cdot 2$ & 7.6 & $0 \cdot 3$ & 0.3 \\
\hline Calcium $(\mathrm{g} / \mathrm{kg})$ & $5 \cdot 6$ & $5 \cdot 6$ & $5 \cdot 8$ & $5 \cdot 6$ & $5 \cdot 6$ \\
\hline $\mathrm{Zn}(\mathrm{mg} / \mathrm{kg})$ & $24 \cdot 0$ & $29 \cdot 2$ & $42 \cdot 7$ & $23 \cdot 4$ & $42 \cdot 9$ \\
\hline Iron $(\mathrm{mg} / \mathrm{kg})$ & $124 \cdot 8$ & $133 \cdot 5$ & $146 \cdot 6$ & $125 \cdot 2$ & $125 \cdot 2$ \\
\hline Cd: Diet $(\mu \mathrm{g} / \mathrm{kg})$ & $15 \cdot 6$ & $35 \cdot 4$ & $29 \cdot 3$ & $34 \cdot 8$ & 11.7 \\
\hline Test meal $(\mu \mathrm{g} / \mathrm{kg})$ & $17 \cdot 6$ & $37 \cdot 4$ & $31 \cdot 3$ & $36 \cdot 8$ & $13 \cdot 7$ \\
\hline
\end{tabular}

Vitamin fortification $(\mathrm{mg} / \mathrm{kg}$ total diet): tocopherol 118 , retinol $4 \cdot 5$, ergocalciferol $44 \mu \mathrm{g}$, thiamin chloride 14 , riboflavin phosphate 13 , pyridoxine chloride 7 , nicotinamide 33 , myo-inositol 66 , biotin $30 \mu \mathrm{g}, 4$-aminobenzoic acid 66 , calcium pantothenate 33 , folic acid $1 \cdot 3$, cyanocobalamin $20 \mu \mathrm{g}$, choline chloride $0.9 \mathrm{~g}$.

Mineral fortification (mg/kg total diet): $\mathrm{CuSO}_{4} \cdot 5 \mathrm{H}_{2} \mathrm{O} 11, \mathrm{KI} 17, \mathrm{CoCl}_{2} \cdot \mathrm{H}_{2} \mathrm{O} 0 \cdot 5, \mathrm{ZnSO}_{4} .7 \mathrm{H}_{2} \mathrm{O} 34$, $\mathrm{MnSO}_{2}, \mathrm{H}_{2} \mathrm{O} 84, \mathrm{FeSO}_{4}, 7 \mathrm{H}_{2} \mathrm{O} 565, \mathrm{MgSO}_{4}, 7 \mathrm{H}_{2} \mathrm{O} 2085, \mathrm{NaCl} 2480, \mathrm{NaH}_{2} \mathrm{PO}_{4} \cdot \mathrm{H}_{2} \mathrm{O} 3735, \mathrm{CaCO}_{3} 7915$ and $\mathrm{KH}_{2} \mathrm{PO}_{4} 8105$.

* For details, see pp. 200-201.

$\uparrow$ Prepared from refined wheat flour; for details, see pp. 200-201.

\$ Prepared from whole-wheat flour.

$\S$ Half the wheat-endosperm flour replaced by bran.

wheat-endosperm crispbread for both experiments was prepared from unenriched, refined wheat flour $(70 \%$ extraction rate) with deionized water, margarine, yeast, sugar and salt. The unleavened dough was baked for $15 \mathrm{~min}$ at $180^{\circ}$ in a hot-air oven. The bread was pulverized before being mixed with an equal amount of the basic diet. The whole-wheat bread used in Expt 2 was made by substituting whole-wheat flour for all the wheatendosperm flour in the previously described recipe. The bran-enriched crispbread was made by substituting wheat bran for half the wheat-endosperm flour in the recipe. $\mathrm{CdCl}_{2}$ was added to the dough for making one batch of endosperm bread and $\mathrm{ZnCl}_{2}$ was added to another in order to make their concentrations in the breads as high as those in the wholewheat and bran-enriched breads.

Radionuclide-labelled test meals were prepared for each group in both experiments from $17.5 \mathrm{~g}$ (dry weight) pulverized bread to which $2.59 \mathrm{MBq}{ }^{109} \mathrm{CdCl}_{2}$ (New England Nuclear, Boston, MA, USA) in $1.0 \mathrm{ml} 0.1 \mathrm{M}-\mathrm{HCl}$ was added. Each bread was then dried at $90^{\circ}$ for $2 \mathrm{~d}$ and mixed with $17.5 \mathrm{~g}$ (dry weight) of the basic diet.

\section{Experimental designs}

Expt 1. Each of the five groups of 5-week-old male rats was fed on the same endosperm diet and deionized water ad lib. After 1 week on the diet the rats were deprived of food but not water for $12 \mathrm{~h}$ and then given a $5 \mathrm{~g}$ test meal of the diet containing $370 \mathrm{kBq}{ }^{109} \mathrm{Cd}$. At $3 \mathrm{~h}$ after the rats were given the ${ }^{109} \mathrm{Cd}$-labelled test meals, when the rats had eaten most of the test meal, the uneaten labelled test meals were weighed and replaced with the unlabelled diet. The faeces were collected starting directly after the administration of the test meal and continuing until the rats were killed. The five groups of rats were killed by exsanguination 
under diethyl ether anaesthesia at 3,6,12, 24 and $48 \mathrm{~h}$ after the removal of the test meal respectively. The stomach and the intestine with their contents and the liver and kidneys were quickly removed and placed in plastic tubes.

Expt 2. Each of the five groups of 3-week-old male rats was fed on one of the five different diets (Table 1) and deionized water ad lib. for 6 weeks. After 3 weeks on the diets the rats were deprived of food but not water for $12 \mathrm{~h}$ and were then given a $5 \mathrm{~g}$ test meal of their respective diets containing $370 \mathrm{kBq}{ }^{109} \mathrm{Cd} .5 \mathrm{~h}$ after the rats were given the ${ }^{109} \mathrm{Cd}$-labelled test meals the uneaten test meal was weighed and replaced by the respective unlabelled diets. The faeces were collected each day for $10 \mathrm{~d}$ after the administration of the labelled test meals. The rats were fed on these diets until they were killed by exsanguination under diethyl ether anaesthesia 3 weeks later.

At death the entire liver was removed and weighed. Both kidneys were removed. Four samples from the liver and the kidneys were placed in separate, weighed, acid washed, borosilicate tubes and the fresh weights were recorded. The samples of faeces and the remainder of the liver were placed in plastic tubes.

\section{${ }^{109} \mathrm{Cd}$ measurements}

The ${ }^{109} \mathrm{Cd}$ activity in the faeces, stomach (Expt 1), intestine (Expt 1), kidneys and liver were measured using a Packard Auto-Gamma Model 5330 spectrometer with a $74 \times 84 \mathrm{~mm} \mathrm{NaI}$ (Tl) through-hole scintillation detector. The counting rates from $3.7 \mathrm{kBq}{ }^{109} \mathrm{Cd}$ in appropriate volumes in similar tubes were measured as references. The background counting rate was recorded and subtracted from the sample and reference counting rates.

The fractional uptake $(\%)$ in the liver and kidneys of the ${ }^{109} \mathrm{Cd}$ from the test meal was calculated by dividing the ${ }^{109} \mathrm{Cd}$ activity in the whole liver and the kidneys together by the ${ }^{109} \mathrm{Cd}$ activity consumed. In Expt 1 the amount of ${ }^{109} \mathrm{Cd}$ consumed was calculated by adding the amount of ${ }^{109} \mathrm{Cd}$ in the intestine, its contents and the faeces to the uptake of ${ }^{109} \mathrm{Cd}$ in the body. In Expt 2 the ${ }^{109} \mathrm{Cd}$ consumed was calculated by adding the amount of ${ }^{109} \mathrm{Cd}$ in the collected faeces to the uptake of ${ }^{109} \mathrm{Cd}$ in the body. The uptake of ${ }^{109} \mathrm{Cd}$ in the body in both experiments was assumed to be 1.4 times the combined ${ }^{109} \mathrm{Cd}$ activity in the liver and kidneys (Kello \& Kostial, 1977). The Cd content in the liver and kidneys which derived from $1 \mathrm{~g}$ of the diet was calculated by multiplying the fractional ${ }^{109} \mathrm{Cd}$ uptake in each sample by the $\mathrm{Cd}$ concentration in the respective diet. It was assumed that the ${ }^{109} \mathrm{Cd}$ in the test meal exchanged freely with the dietary $\mathrm{Cd}$ and, thus, represented it.

\section{Cd determinations}

Four liver samples and one kidney from each rat in Expt 2 and ten samples of each of the five diets were dried to constant weight for $2 \mathrm{~d}$ at $110^{\circ}$ and digested in a total of $5-7 \mathrm{ml}$ concentrated $\mathrm{HNO}_{3}$ and $3-5 \mathrm{ml} \mathrm{H}_{2} \mathrm{O}_{2}(300 \mathrm{ml} / 1)$ in several steps with evaporation after each step. The samples were stored in an incubator and the temperature was increased gradually from 45 to $120^{\circ}$ during the digestion process. When the samples were optimally digested they were evaporated to dryness at $90^{\circ}$ and dissolved in $4 \mathrm{ml} 0.5 \mathrm{M}-\mathrm{HNO}_{3}$. The $\mathrm{Cd}$ contents were determined by the method of standard addition using a Perkin-Elmer Model 3030 atomic absorption spectrophotometer equipped with deuterium background corrector, autosampler (Model AS-40) and graphite furnace (Model HGA-500). A pyrolytic graphite tube with a platform was used. Known amounts of Cd dissolved in $0.5 \mathrm{M}$ $\mathrm{HNO}_{3}$ served as references.

The accuracy and reproducibility of the method for $\mathrm{Cd}$ determination was assessed using US National Bureau of Standards bovine liver (no. 1577a) and wheat flour (no. 1567) which were analysed in the same way as the samples in the present study. The ranges for 
the bovine liver and wheat flour certified by NBS were 380-500 and 25-39 ng Cd/g dry weight respectively. Our mean values for ten determinations each of bovine liver and wheat flour were $440 \cdot 1$ (SD 27.4) and $28 \cdot 2$ (SD 1.6) ng Cd/g respectively.

The amount of $\mathrm{Cd}$ accumulated in the liver and kidneys during Expt 2 was calculated by subtracting from the $\mathrm{Cd}$ content in these tissues at the end of the experiment the mean $\mathrm{Cd}$ contents in these organs from six rats which were killed at the start of the experiment. The mean $\mathrm{Cd}$ contents in the liver and kidneys of these 3 -week-old rats were $6.2(\mathrm{SD} 1 \cdot 1)$ and 2.9 (SD 0.8 ) ng respectively. Thus, the average total initial amount of $\mathrm{Cd}$ in the liver and both kidneys together was $9 \cdot 1 \mathrm{ng}$. The estimated food intake was calculated by dividing the amount of $\mathrm{Cd}$ accumulated in the liver and kidneys together by the $\mathrm{Cd}$ content in the liver and the kidneys which derived from $1 \mathrm{~g}$ diet as measured using ${ }^{109} \mathrm{Cd}$ in a test meal.

\section{Phytic acid and dietary fibre measurements}

The phytic acid concentrations in the five diets were determined using the method of Ellis et al. (1977) as modified by Sandberg et al. (1982). The dietary fibre concentrations were determined using a method according to Asp et al. (1983).

\section{Statistics}

The means for a given variable in the five groups in each experiment were tested using a one-way analysis of variance $(F)$ after the variances had been tested using Bartlett's test of homogeneity of variance $\left(\chi^{2}\right)$. If a statistically significant result was obtained in the analysis of variance, the differences among group means were tested using least significant differences (Snedecor \& Cochran, 1980). In all statistical tests the null hypothesis was rejected at $P \leqslant 0 \cdot 01$.

\section{RESULTS}

The rats grew normally on these crispbread diets and there were no significant differences among group means for gain in body weight during the experiment (Table 2). There were no signs of illness or deficiency.

The group mean fractions of the $5 \mathrm{~g}$ test meal which were consumed in Expt 1 were between 76 and $89 \%$ and there were no significant differences among the group means $(F=1 \cdot 3, P>0.05)$. In Expt 2 , the five groups of rats ate on average between 75 and $81 \%$ of the test meal and there were no significant differences among the group means $(F=0 \cdot 2$, $P>0.05)$.

\section{Expt 1}

The fractional uptake of ${ }^{109} \mathrm{Cd}$ in the liver and kidneys was significantly higher at 24 and $48 \mathrm{~h}$ after the test meal than it was at earlier times (Fig. 1). The mean fractional uptake in the liver and kidneys combined differed significantly among the groups killed at 3,6 and $12 \mathrm{~h}$ but there was no significant difference between the groups killed at 24 and $48 \mathrm{~h}$ after the test meal.

\section{Expt 2}

${ }^{109} \mathrm{Cd}$ activity. The mean fractional uptake of ${ }^{109} \mathrm{Cd}$ in the liver and kidneys together in the groups given whole-wheat or bran crispbread diets was between 34 and $48 \%$ lower than that in the three groups given the endosperm crispbread diets (Table 2). There were no significant differences in the fractional ${ }^{109} \mathrm{Cd}$ uptake among the groups given the endosperm diet and the endosperm diets supplemented with $\mathrm{Zn}$ (endosperm $+\mathrm{Zn}$ ) or $\mathrm{Cd}$ (endosperm $+\mathrm{Cd}$ ) to the whole-wheat and bran diet levels.

The $\mathrm{Cd}$ contents of the liver and kidneys which derived from $1 \mathrm{~g}$ diet (the fractional uptake of ${ }^{109} \mathrm{Cd}$ multiplied by the respective diet $\mathrm{Cd}$ concentration) were significantly higher 
Table 2. Mean body weight increase during the entire experiment, fractional accumulation of ${ }^{109} \mathrm{Cd}$ from the test meal, amount of $\mathrm{Cd}$ in the liver and kidneys which derived from $1 \mathrm{~g}$ diet and $C d$ accumulated in the liver and kidneys of rats during the 6-week experiment*

(Mean values with their standard errors for six rats per group)

\begin{tabular}{|c|c|c|c|c|c|c|c|c|}
\hline \multirow[b]{2}{*}{ Diet group } & & \multirow{2}{*}{$\begin{array}{c}\text { Body wt } \\
\text { increase } \\
\text { (g) }\end{array}$} & \multicolumn{2}{|c|}{$\begin{array}{c}{ }^{109} \mathrm{Cd} \text { from test } \\
\text { meal }(\%)\end{array}$} & \multicolumn{2}{|c|}{$\begin{array}{l}\text { Cd from } 1 \mathrm{~g} \\
\operatorname{diet}(\mathrm{ng}) \dagger\end{array}$} & \multicolumn{2}{|c|}{$\begin{array}{c}\text { Cd accumulation } \\
\text { (ng) } \ddagger\end{array}$} \\
\hline & & & Liver & Kidneys & Liver & Kidneys & Liver & Kidneys \\
\hline \multirow[t]{2}{*}{ Endosperm: } & Mean & $190-7$ & $0 \cdot 161^{\mathrm{b}}$ & $0.061^{\mathrm{b}}$ & $0.026^{\mathrm{a}}$ & $0 \cdot 010^{\mathrm{ab}}$ & $16 \cdot 8^{\mathrm{a}}$ & $5 \cdot 9^{\mathrm{a}}$ \\
\hline & $\mathrm{SE}$ & $5 \cdot 1$ & 0.006 & 0.005 & 0.001 & 0.001 & $2 \cdot 3$ & 0.8 \\
\hline \multirow[t]{2}{*}{ Whole wheat: } & Mean & $209 \cdot 9$ & $0 \cdot 112^{\mathrm{a}}$ & $0.035^{\mathrm{a}}$ & $0.039^{\mathrm{b}}$ & $0.012^{b}$ & $25 \cdot 5^{b}$ & $7 \cdot 7^{\mathrm{a}}$ \\
\hline & $\mathrm{SE}$ & $7 \cdot 7$ & 0.011 & 0.004 & 0.004 & $0 \cdot 001$ & $1 \cdot 3$ & 0.6 \\
\hline \multirow[t]{2}{*}{ Bran: } & Mean & $212 \cdot 1$ & $0 \cdot 100^{\mathrm{a}}$ & $0.031^{2}$ & $0.029^{a b}$ & $0.009^{a b}$ & $21 \cdot 3^{\mathrm{ab}}$ & $6 \cdot 4^{a}$ \\
\hline & SE & 6.6 & 0.008 & 0.003 & 0.002 & $0 \cdot 001$ & $2 \cdot 3$ & $1 \cdot 1$ \\
\hline \multirow{2}{*}{ Endosperm $+\mathrm{Cd}$ : } & Mean & $206 \cdot 9$ & $0 \cdot 173^{\mathrm{b}}$ & $0.059^{\mathrm{b}}$ & $0 \cdot 060^{\mathrm{c}}$ & $0.021^{\mathrm{C}}$ & $33 \cdot 7^{c}$ & $13 \cdot 2^{\mathrm{b}}$ \\
\hline & $\mathrm{SE}$ & $7 \cdot 3$ & 0.009 & 0.004 & 0.003 & 0.001 & 1.7 & $1 \cdot 1$ \\
\hline \multirow[t]{2}{*}{ Endosperm + zinc: } & Mean & $214 \cdot 7$ & $0 \cdot 184^{\mathrm{b}}$ & $0.068^{b}$ & $0.022^{\mathrm{a}}$ & $0 \cdot 008^{\mathrm{a}}$ & $14 \cdot 9^{\mathrm{a}}$ & $5 \cdot 9^{\mathrm{a}}$ \\
\hline & $\mathrm{SE}$ & $2 \cdot 4$ & 0.013 & $0 \cdot 003$ & 0.002 & $<0.001$ & 0.6 & 0.7 \\
\hline$F$ & & $2 \cdot 4$ & 14 & 20 & 34 & 26 & 18 & 11 \\
\hline \multicolumn{9}{|c|}{ Statistical significance: } \\
\hline \multicolumn{2}{|c|}{$P$} & $>0.05$ & $<0.001$ & $<0.001$ & $<0.001$ & $<0.001$ & $<0.001$ & $<0.001$ \\
\hline \multicolumn{2}{|l|}{ LSD } & - & 0.039 & 0.014 & 0.010 & $0 \cdot 004$ & $6 \cdot 9$ & $3 \cdot 5$ \\
\hline
\end{tabular}

$a, b, c$, Means with unlike superscript letters differ by more than $\operatorname{LSD}_{\mathbf{0} 01}$.

LSD, least significant difference.

* For details of diets and experimental procedures, see Table 1 and pp. 200-203.

$\dagger \mathrm{Cd}$ from $1 \mathrm{~g}$ diet $=\left(\%{ }^{109} \mathrm{Cd}\right.$ from test meal $\left./ 100\right) \times(\mathrm{Cd}$ in diet $)$.

‡ Cd accumulation = total $\mathrm{Cd}$ content $-6.2 \mathrm{ng} \mathrm{Cd}$ (liver) or $2.9 \mathrm{ng} \mathrm{Cd}$ (kidneys); the values of 6.2 and $2.9 \mathrm{ng} \mathrm{Cd}$ represent the mean Cd content in the liver and kidneys respectively of six 3-week-old rats of the same strain from the same supplier.

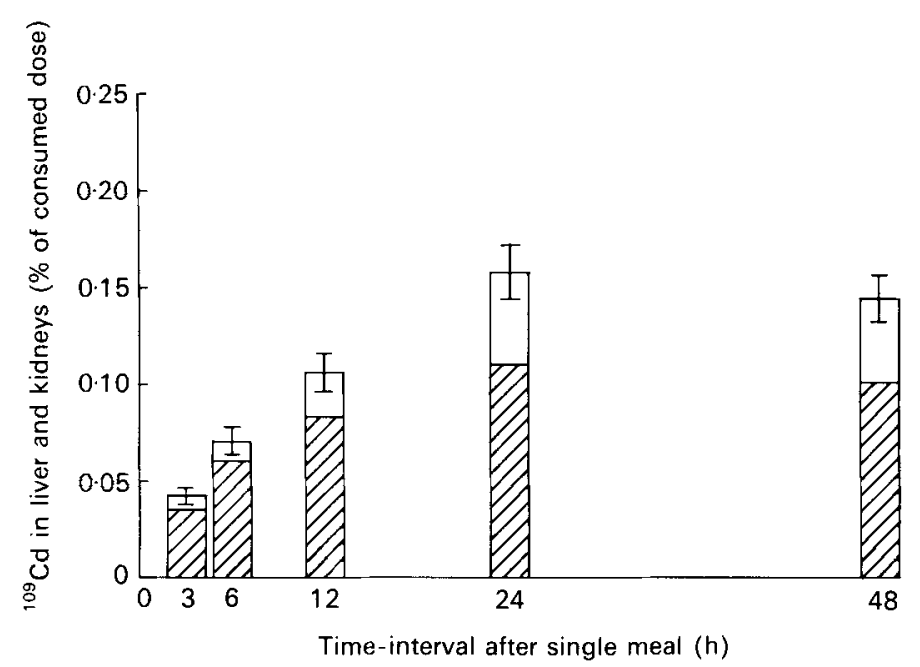

Fig. 1. Expt 1. The ${ }^{109} \mathrm{Cd}$ activities in the liver $(\square)$ and kidneys $(\square)$ of rats after they were given the ${ }^{109} \mathrm{Cd}$-labelled test meal, expressed as percentage consumed activity. Values are means with their standard errors (represented by vertical bars) for the combined activities in the liver and kidneys. For details of experimental procedures, see pp. 201-203. 
in the groups of rats fed on the endosperm $+\mathrm{Cd}$ diet than that in any of the other four groups (Table 2). The mean liver Cd content which derived from $1 \mathrm{~g}$ whole-wheat diet was significantly higher than that from either the endosperm diet or the endosperm $+\mathrm{Zn}$ diets. The Cd content in the kidneys which derived from $1 \mathrm{~g}$ whole-wheat diet was significantly higher than that from the endosperm $+\mathrm{Zn}$ diet.

Cd accumulation. The $\mathrm{Cd}$ accumulation in both the liver and the kidneys in the group given the endosperm $+\mathrm{Cd}$ diet was significantly higher than the $\mathrm{Cd}$ accumulated in the liver and kidneys in all the other groups (Table 2). There were no significant differences in $\mathrm{Cd}$ accumulation in the kidneys among the other four groups but the $\mathrm{Cd}$ accumulation in the liver was significantly higher in the group given the whole-wheat diet than in the groups given the endosperm and endosperm $+\mathrm{Zn}$ diets.

\section{DISCUSSION}

Different methods may be used for measuring the absorption of $\mathrm{Cd}$ from the diet and its accumulation in the body, and the results may differ depending on the choice of method and the accuracy and precision of the method in the particular study. One measure for the absorption and accumulation of $\mathrm{Cd}$ is the concentration or total amount of $\mathrm{Cd}$ in an organ or tissue after a defined period of time on a test diet. Such experiments measure Cd accumulation directly but they are time-consuming. The retention of a radioisotope of $\mathrm{Cd}$ from a single meal in an organ or tissue or the whole body is a method often used in shortterm experiments. The results with this type of measurement should represent the fractional absorption and accumulation of $\mathrm{Cd}$ from the diet at the time of administration (Welch et al. 1979).

In an earlier study in rats (Moberg et al. 1987) we used both methods and the results were not in agreement on the accumulation of $\mathrm{Cd}$ from diets with and without wheat bran. The amount of $\mathrm{Cd}$ accumulated in the liver and kidneys after 6 weeks on the diets was 1.5-3 times higher than that in the present study and much greater than that which could be estimated from the fractional Cd absorption $\left(\%{ }^{109} \mathrm{Cd}\right)$ and diet $\mathrm{Cd}$ concentrations. While the fractional $\mathrm{Cd}$ absorption and retention in the group fed on a wheat-bran diet was significantly lower than that in the group fed on a wheat-endosperm diet with $\mathrm{Cd}$ added to the bran diet level, the $\mathrm{Cd}$ accumulated in these organs after 6 weeks on the diets did not confirm this difference in the earlier study.

One reason for these differences may have been that the $\mathrm{Cd}$ concentrations determined by AAS in the earlier study were too high due to contamination of the samples with Cd during sample preparation. The mean Cd concentration in ten samples of NBS bovine liver determined in the earlier study was 460 (SD 9) $\mathrm{ng} \mathrm{Cd/g}$ dry weight, while the mean for ten samples in the present study was 440 (SD 27) $\mathrm{ng} \mathrm{Cd/g}$ dry weight. The difference is nearly significant $(P=0.047)$ and is more than sufficient to account for the differences in the $\mathrm{Cd}$ accumulated in the kidneys and livers in the two studies. As no Cd was detected in the blanks in either study, there is no reason to believe that the samples were contaminated with $\mathrm{Cd}$ from the atmosphere or the chemicals used to dissolve the samples. The samples in the earlier study were dry ashed for $2 \mathrm{~d}$ at $550^{\circ}$ in acid-washed borosilicate tubes. It is possible that these samples reacted with the surface of the glass tubes during ashing, causing Cd to be released from the glass. In Expt 2 of the present study the samples were digested in $\mathrm{HNO}_{3}$ and $\mathrm{H}_{2} \mathrm{O}_{2}$ in glass tubes which had been boiled in concentrated $\mathrm{HNO}_{3}$ in an effort to reduce or eliminate these possible sources of error. It would appear that these efforts were successful.

Another reason for the discrepancies between the results with the two methods in the earlier study may have been that the fractional $\mathrm{Cd}$ absorption $\left(\%{ }^{109} \mathrm{Cd}\right)$ from test meals 


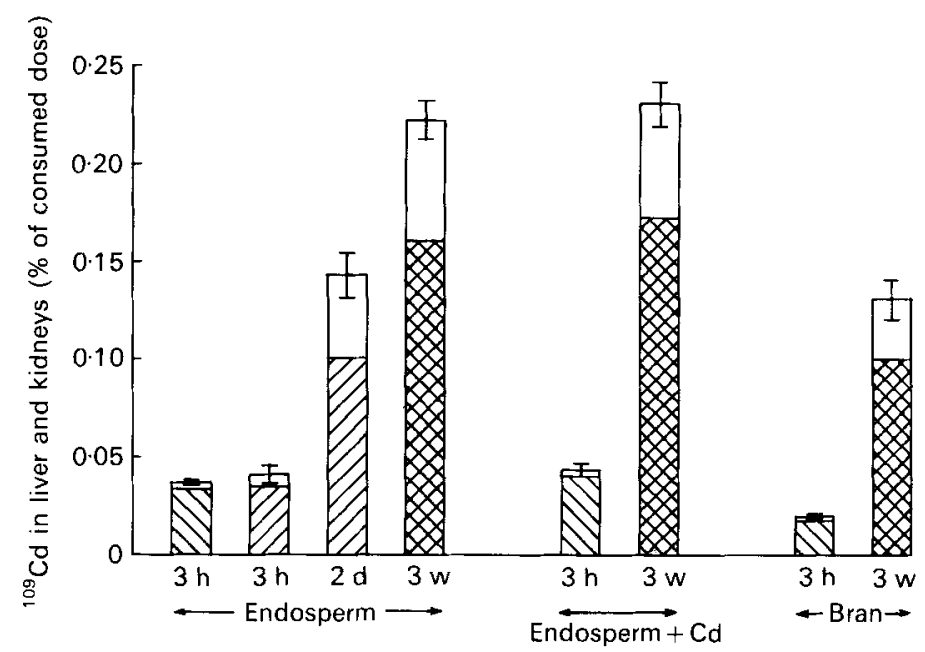

Fig. 2. Expts 1 and 2. The ${ }^{109} \mathrm{Cd}$ activity in the liver $(\square, \square, \bigotimes)$ and kidneys $(\square)$ of rats $3 \mathrm{~h}, 2 \mathrm{~d}$ and 3 weeks after they were given the ${ }^{109} \mathrm{Cd}$-labelled test meal, expressed as percentage consumed activity in Expts $1(\bigotimes)$ and $2(\bigotimes)$ in the present study ( $\mathrm{Q}$ ) and in an earlier experiment (Moberg et al. 1987). Values are means with their standard errors represented by vertical bars, for the combined activities in the liver and kidneys. For details of experimental procedures, see pp. 201-203.

of the diet may have been too low. There was still a considerable amount of radioisotope in the intestinal mucosa when the measurements were made $3 \mathrm{~h}$ after the labelled diet had been removed and it was not known how much of this activity would eventually be absorbed. Expt 1 in the present study was undertaken in order to determine the time-course of the absorption of ${ }^{109} \mathrm{Cd}$ from a test meal. As Cd absorption is known to change with age (Nordberg et al. 1985), the ${ }^{109} \mathrm{Cd}$-labelled test meal was given when the rats were 6 weeks old in both Expts 1 and 2. The results of Expt 1 (Fig. 1) showed that the fractional absorption of ${ }^{109} \mathrm{Cd}$ measured $3 \mathrm{~h}$ after the test meal was about one-third of that measured $48 \mathrm{~h}$ after the test meal. In Expt 2 the fractional absorption of ${ }^{109} \mathrm{Cd}$ was measured 3 weeks after the test meal and the activities in the liver and kidneys from the rats given the wheat-endosperm diet were almost $40 \%$ greater than those $48 \mathrm{~h}$ after the test meal in Expt 1 (Fig. 2). As very little ${ }^{109} \mathrm{Cd}$ remained in the intestine after $48 \mathrm{~h}$, it is unlikely that this difference represents further ${ }^{109} \mathrm{Cd}$ absorption from the test meal and far more likely that a redistribution of ${ }^{109} \mathrm{Cd}$ in the body occurs after $48 \mathrm{~h}$. This conclusion is consistent with findings presented by Lucis et al. (1969) on the changes in the distribution of ${ }^{109} \mathrm{Cd}$ in rats with time after a subcutaneous injection.

We have also compared the results of the fractional absorption of ${ }^{109} \mathrm{Cd}$ in the liver and kidneys from Expt 1 and 2 in the present study (Fig. 2) with those from the earlier study (Moberg et al. 1987), despite the fact that the rats were 9 weeks old when they were given the ${ }^{109} \mathrm{Cd}$ test meal in the earlier study and 6 weeks old in Expt 1 of the present study. The mean fractional uptake of ${ }^{109} \mathrm{Cd}$ after $3 \mathrm{~h}$ did not differ between the groups given the endosperm diets. The mean fractional absorption of ${ }^{109} \mathrm{Cd}$ from endosperm, endosperm $+\mathrm{Cd}$ and wheat-bran diets 3 weeks after the test meal in Expt 2 in the present study was in each case about six times that found $3 \mathrm{~h}$ after the test meal in the earlier experiment. In both experiments the $\mathrm{Cd}$ endogenous to the endosperm diets was absorbed to the same extent as the exogenous $\mathrm{CdCl}_{2}$ added to the endosperm diet, while the $\mathrm{Cd}$ endogenous to the bran diet was absorbed less readily. The fractional absorption of ${ }^{109} \mathrm{Cd}$ from the bran diets was approximately $60 \%$ of that from the endosperm diets. Thus, the results of the 
present study with respect to the relative absorption of $\mathrm{Cd}$ among the three diets are in good agreement with those of the earlier study despite the differences in the age of the rats and the time which passed between the test meal and the measurement of retained ${ }^{109} \mathrm{Cd}$ activity.

In the earlier study there was no significant difference between the accumulation of $\mathrm{Cd}$ in the liver and kidneys in the rats given the bran diet and that in the rats given the endosperm diet with $\mathrm{Cd}$ added to the bran diet level. In Expt 2 of the present study the accumulation of $\mathrm{Cd}$ in the liver and kidneys of the bran group was about $60 \%$ of that in the endosperm $+\mathrm{Cd}$ group and they differed significantly (Table 2). In the present study there was relatively good agreement between the results of the two methods in the comparison of the absorption and accumulation of $\mathrm{Cd}$ from different wheat fractions. Both the fractional ${ }^{109} \mathrm{Cd}$ retention and the accumulated amount of $\mathrm{Cd}$ in the liver and kidneys relative to the dietary $\mathrm{Cd}$ concentration demonstrate that some factor in the whole-wheat and wheat-bran diets has an effect on the fractional absorption of $\mathrm{Cd}$. As supplementation of endosperm diets with either $\mathrm{Zn}$ or $\mathrm{Cd}$ to the levels in whole-wheat and bran diets did not affect relative $\mathrm{Cd}$ accumulation, it may be that the higher dietary fibre or phytate concentrations in the whole-wheat and bran diets were responsible for the reduction in $\mathrm{Cd}$ accumulation. Omori \& Muto (1977) and Kiyozumi et al. (1982) have demonstrated lower $\mathrm{Cd}$ absorption from diets rich in different types of dietary fibre, which Kiyozumi et al. (1982) attributed to their ability to bind Cd. Jackl et al. (1985) demonstrated that phytate in the diet causes a considerable decrease in the intestinal absorption of $\mathrm{Cd}$, presumably due to its ability to build complexes with $\mathrm{Cd}$.

The results showed that supplementation of the endosperm diet with $\mathrm{Zn}$ to the level of the wheat-bran diet did not influence the absorption and accumulation of $\mathrm{Cd}$. Lamphere et al. (1984) showed that high doses of $\mathrm{Zn}(600 \mathrm{mg} / \mathrm{kg} \mathrm{diet})$ decrease the Cd accumulation in liver, kidneys and muscle in calves. However, the dietary $\mathrm{Cd}$ concentration was also high $(50 \mathrm{mg} / \mathrm{kg})$ and not relevant for human exposure. These differences in dietary $\mathrm{Zn}$ and $\mathrm{Cd}$ concentrations may explain the difference in results. At levels of $\mathrm{Cd}$ and $\mathrm{Zn}$ exposure which are relevant for humans, low $\mathrm{Zn}$ intake may result in increased $\mathrm{Cd}$ absorption (Jacobs $e t$ al. 1977). The $\mathrm{Zn}$ concentration in the endosperm diet in the present study was $24 \mathrm{mg} / \mathrm{kg}$, which is not low enough to cause such an effect.

The accumulation of $\mathrm{Cd}$ from $1 \mathrm{~g}$ test diet in the liver and kidneys of the rats in Expt 2, calculated from the ${ }^{109} \mathrm{Cd}$ retention, shows nearly the same pattern among the five diet groups as the total accumulation of stable $\mathrm{Cd}$ in these organs determined by AAS (Table 2). If both methods give accurate measures of the accumulation of $\mathrm{Cd}$ in the liver and kidneys in Expt 2, then it should be possible to estimate the total food intake by dividing the accumulated amount of $\mathrm{Cd}$ in the liver and kidneys together by the product of the combined fractional ${ }^{109} \mathrm{Cd}$ absorption in these organs and the respective $\mathrm{Cd}$ concentration in the diet. The estimated means for food intake in the five diet groups were between 587 and $763 \mathrm{~g}$ diet for the 6 weeks, or $14-18 \mathrm{~g} / \mathrm{d}$, which is normal food intake for healthy male rats between 3 and 9 weeks of age consuming a nutritionally adequate diet (Warner $\&$ Breuer, 1972). This indicates that the systematic errors in the measurements of both $\mathrm{Cd}$ concentrations and ${ }^{109} \mathrm{Cd}$ retention must have been reduced considerably by the changes we made in the methods. It also indicates that the accumulation of $\mathrm{Cd}$ in these organs could be estimated by multiplying the fractional ${ }^{109} \mathrm{Cd}$ absorption from a single meal by the $\mathrm{Cd}$ concentration in the diet and the food intake. However, the time necessary for the ${ }^{109} \mathrm{Cd}$ activity to become representative for $\mathrm{Cd}$ accumulation is almost as long as is necessary to measure the direct effect on the Cd content.

In both the present study and the earlier study (Moberg et al. 1987) the mean fractional $\mathrm{Cd}$ accumulation in the liver and kidneys together was at most $0.25 \%$, which is lower than 
earlier reported values of about $1 \%$ (Engström \& Nordberg, 1979) This low absorption level may be due to the relatively high Fe concentration in the diet. Flanagan et al. (1978) found higher $\mathrm{Cd}$ absorption in mice with low Fe status than in mice with high Fe status.

In conclusion, the $\mathrm{Cd}$ accumulation in the liver and kidneys and the absorption and retention of ${ }^{109} \mathrm{Cd}$ from a test meal both show that some factor or factors in the whole-grain and bran fractions of wheat decrease the fractional absorption and accumulation of $\mathrm{Cd}$. This reduction may have been due to the higher dietary fibre and phytate concentrations in the whole-wheat and bran diets, but it was in all probability not due to the higher $\mathrm{Zn}$ or Cd concentrations, or both. The reduction in fractional $\mathrm{Cd}$ absorption from the wholewheat and bran diets does not fully compensate for the higher exposure to $\mathrm{Cd}$ from these diets. While measurements of the fractional retention of ${ }^{109} \mathrm{Cd}$ in the liver and kidneys made a few hours to a few days after administration of labelled test meals of different diets provide good relative measures of $\mathrm{Cd}$ accumulation from the diets, they cannot be used to make accurate estimates of $\mathrm{Cd}$ accumulation in these organs.

The author wishes to thank Ms Inger Sjöström and Ms Ulla-Stina Kågström for skilful technical assistance, and Wasabröd $\mathrm{AB}$ for the analyses of the nutrients in the composite diets. This study was supported by the Swedish Council for Planning and Coordination of Research (FRN) and the Swedish Council for Forestry and Agricultural Research (SJFR).

\section{REFERENCES}

Asp, N.-G., Johansson, C.-G., Hallmer, H. \& Siljeström, M. (1983). A rapid enzymatic method for assay of insoluble and soluble dietary fibre. Journal of Agricultural and Food Chemistry 31, 476482.

de Boland, A. R., Garner, G. B. \& O'Dell, B. L. (1975). Identification and properties of 'phytate' in cereal grains and oilseed products. Journal of Agricultural and Food Chemistry 23, 1186-1189.

Elinder, C.-G. (1985a). Cadmium: uses, occurrence, and intake. In Cadmium and Health: A Toxicological and Epidemiological Appraisal: Exposure, Dose and Metabolism, vol. 1, pp. 23-63 [L. Friberg, C.-G. Elinder, T. Kjellström and G. Nordberg, editors]. Boca Raton, Florida: CRC Press.

Elinder, C.-G. (1985b). Normal values for cadmium in human tissues, blood and urine in different countries. In Cadmium and Health: A Toxicological and Epidemiological Appraisal: Exposure, Dose and Metabolism, vol. 1, pp. 81-102 [L. Friberg, C.-G. Elinder, T. Kjellström and G. Nordberg, editors]. Boca Raton, Florida: CRC Press.

Ellis, R., Morris, E. R. \& Philpot, C. (1977). Quantitative determination of phytate in the presence of high inorganic phosphate. Analytical Biochemistry 77, 536-539.

Engström, B. \& Nordberg, G. F. (1979). Factors influencing absorption and retention of oral ${ }^{109} \mathrm{Cd}$ in mice: age, pretreatment and subsequent treatment with non-radioactive cadmium. Acta Pharmacologica et Toxicologica 45, 315-324.

Flanagan, P. R., McLellan, J. S., Haist, J., Cheran, G., Chamberlain, M. J. \& Valberg, L. S. (1978). Increased dietary cadmium absorption in mice and human subjects with iron deficiency. Gastroenterology 74, 841-846.

Gartrell, M. J., Crawn, J. C., Podrebarac, D. S. \& Gundersson, E. L. (1986). Pesticides, selected elements, and other chemicals in adult total diet samples, October 1980-March 1982. Journal of the Association of Official Analytical Chemists 69, 160-161.

Jackl, G. A., Rambeck, W. A. \& Kollmer, W. E. (1985). Retention of cadmium in organs of the rat after a single dose of labeled cadmium-3-phytate. Biological Trace Element Research 7, 69-74.

Jacobs, R. M., Fox, M. R. S., Jones, A. O. L., Hamilton, R. P. \& Lener, J. (1977). Cd metabolism: individual effects of $\mathrm{Zn}, \mathrm{Cu}$ and $\mathrm{Mn}$. Federation Proceedings 36, 1152.

Jorhem, L., Mattsson, P. \& Slorach, S. (1984). Lead, cadmium, zinc and certain other metals in foods on the Swedish market. Vår Föda 36, suppl. 3.

Kello, D. \& Kostial, K. (1977). Influence of age on whole-body retention and distribution of ${ }^{115 \mathrm{~m}} \mathrm{Cd}$ in the rat. Environmental Research 14, 92-98.

Kiyozumi, M., Miyata, K., Takahashi, Y., Mizunaga, F., Mishima, M., Noda, S., Nakagawa, M. \& Kojima, S. (1982). Studies on poisonous metals. IX. Effects of dietary fibres on absorption of cadmium in rats. Chemical and Pharmaceutical Bulletin 30, 44944499.

Kjellström, T. (1986). Renal effects. In Cadmium and Health: A Toxicological and Epidemiological Appraisal: Effects and Response, vol. 2, pp. 9899 [L. Friberg, C.-G. Elinder, T. Kjellström and G. F. Nordberg, editors]. Boca Raton, Florida: CRC Press.

Lamphere, D. N., Dorn, C. R., Reddy, C. S. \& Meyer, A. W. (1984). Reduced cadmium body burden in cadmium exposed calves fed supplemental zinc. Environmental Research 33, 119-129. 
Lucis, O. J., Lynk, M. E. \& Lucis, R. (1969). Turnover of cadmium 109 in rats. Archives of Environmental Health 18, 307-310.

Moberg, A., Hallmans, G., Sjöström, R. \& Wing, K. R. (1987). The effect of wheat bran on the absorption and accumulation of cadmium in rats. British Journal of Nutrition 58, 383-391.

Nilsson, J. \& Wallgren, B. (1987). Kadmium i miljön-bedömningsgrunder. Rapport no. 3317, Naturvårdsverket. Solna, Sweden: Modin-tryck.

Nordberg, G. F., Kjellström, T. \& Nordberg, M. (1985). Kinetics and metabolism. In Cadmium and Health: A Toxicological and Epidemiological Appraisal: Exposure, Dose and Metabolism, vol. 1, pp. 103-172 [L. Friberg, C.-G. Elinder, T. Kjellström and G. Nordberg, editors]. Boca Raton, Florida: CRC Press.

Omori, M. \& Muto, Y, (1977). Effects of dietary protein, calcium, phosphorus and fibre on renal accumulation of exogenous cadmium in young rats. Journal of Nutritional Science and Vitaminology 23, 361-373.

Sandberg, A.-S., Hasselblad, C., Hasselblad, K. \& Hultén, L. (1982). The effect of wheat bran on the absorption of minerals in the small intestine. British Journal of Nutrition 48, 185-191.

Snedecor, G. W. \& Cochran, W. G. (1980). Statistical Methods, 7th ed. Ames, Iowa: Iowa State University Press.

Vahter, M., Berglund, M., Lind, B., Jorhem, L., Slorach, S. \& Friberg, L. (1991). Personal monitoring of lead and cadmium exposure - a Swedish study with special reference to methodological aspects. Scandinavian Journal of Work Environment and Health 17, 65-74.

Warner, L. G. \& Breuer, L. H. Jr. (1972). Nutrient requirements of the laboratory rat. In Nutrient Requirements of Domestic Animals. No 10. Nutrient Requirements of Laboratory Animals, 2 nd revised ed. Washington, DC: National Academy of Science.

Welch, W. R., House, W. A. \& Van Campen, D. R. (1979). Availability of cadmium from lettuce leaves and cadmium sulfate to rats. Nutritional Reports International 17, 35-42.

World Health Organization (1990). Diet, Nutrition, and the Prevention of Chronic Diseases. Technical Report Series no. 797. Geneva: WHO. 